\title{
Macroalgal decomposition: laboratory studies with particular regard to microorganisms and meiofauna
}

\author{
M. Rieper-Kirchner
}

\author{
Biologische Anstalt Helgoland, Meeresstation; D-W-2192 Helgoland, Germany
}

\begin{abstract}
The microbial degradation of North Sea macroalgae was studied in laboratory microcosms, containing autoclaved seawater and a mixture of equal parts of air-dried Delesseria sanguinea, Ulva lactuca, and Laminaria saccharina (red, green and brown algae, respectively). To determine the influence of different organisms on the decomposition rate (expressed in terms of algal dry weight loss relative to the material present at time zero) and their development during decomposition processes, yeast, flagellates, ciliates, nematodes and a harpacticoid copepod species were introduced to the microcosms. Results show that microbial degradation compared to the controls was enhanced in the presence of non-axenic nematodes (Monhystera sp.) and protozoans, including bacterivorous ciliates (Euplotes sp. and a Uronema-like sp.) and flagellates. No enhancement occurred with yeast (Debaryomyces hansenii) or with the harpacticoid copepod Tisbe holothuriae. The most rapid algal dry weight loss $\left(78.7 \%\right.$ after $14 \mathrm{~d}$ at $\left.18^{\circ} \mathrm{C}\right)$ occurred with the addition of raw seawater sampled near benthic algal vegetation and containing only the natural microorganisms present. These consisted mainly of bacteria with different morphological properties, whereby their numbers alone (viable counts) could not be correlated with algal dry weight loss. Although no single dominant species could be determined, lemon yellow pigmented colonies were frequently found. During decomposition in all microcosms the formation of algal particles $40-400 \mu \mathrm{m}$ was observed, which were rapidly colonized by the other organisms present.
\end{abstract}

\section{INTRODUCTION}

During storms large amounts of macroalgae may be uprooted and fragmented by wave action. In the surf zone algal fragments and particles may accumulate which support large bacteria populations capable of utilizing algal products such as mannitol, alginate, cellulose, and agar (Wolter \& Rheinheimer, 1977; Rieper-Kirchner, 1989). Through the activities of bacteria and fungi, which are the primary agents in decomposition and remineralization processes in aquatic environments (Rheinheimer, 1981), nutrients are rapidly regenerated and made available again for the primary producers (Linley et al., 1981; Lucas et al., 1981; Koop et al., 1982a, b). Dissolved organic compounds may also be converted by bacteria into aggregates, which may in turn be taken up by larger organisms (Lush \& Hynes, 1973; Robertson et al., 1982; Biddanda, 1985; Muschenheim et al., 1989). It is believed that most of the macrophyte production (over $90 \%$ ) in coastal waters of the temperate zones is not directly consumed by grazing herbivores, but goes into the detrital food web (Mann, 1972; Fenchel \& Jørgensen, 1977; Lüning, 1985). 
Algae cast upon the beach may be rapidly colonized and consumed by amphipods and dipteran larvae (Griffiths \& Stenton-Dozey, 1981; Inglis, 1989); large numbers of meiofaunal nematodes may also be associated with rotting algae (Riemann, 1968; Lorenzen et al., 1987; Inglis, 1989; and pers. obs.). The occurrence of members of another large meiofauna taxon, harpacticoid copepods, on fragmenting algae in the surf zone and in sea foam has also been recorded (Robertson \& Hansen, 1982; Armonies, 1989; RieperKirchner, 1989). Among the meiofauna, organisms 42-1000 $\mu \mathrm{m}$ in size (Higgins \& Thiel, 1988), particularly the nematodes and harpacticoids, are known to feed on detritus, microorganisms and also protozoans (see Reviews by Hicks \& Coull, 1983, and Heip et al., 1985).

Although it has been shown that some protozoans may facilitate microbial decomposition processes (Javornický \& Prokešová, 1963; Johannes, 1965; Straškrabová-Prokešová \& Legner, 1966; Barsdate et al., 1974; Harrison \& Mann, 1975; Fenchel \& Harrison, 1976; Briggs et al., 1979), there have been few investigations on the influence of small metazoans on decomposition and remineralization processes (Tenore et al., 1977; Findlay \& Tenore, 1982; Rieper-Kirchner, 1989). In this present study, the effects of the presence of small metazoans as well as protozoans and microorganisms on the decomposition of North Sea macroalgae have been investigated in the laboratory.

\section{MATERIALS AND METHODS}

All laboratory decomposition experiments were performed with 100 -ml screw-cap bottles. In addition to the seawater and organisms described below, each bottle or microcosm contained $0.1 \mathrm{~g}$ dried algae mixture consisting of equal parts of Delesseria sanguinea, Ulva lactuca, and Laminaria saccharina (red, green and brown algae, respectively). The algae were collected from the surf zone of'Helgoland, rinsed briefly with tap water, air-dried and cut into pieces 0.2 to $1.0 \mathrm{~cm}$ long; the pieces were not sterilized. Three types of experiments were performed:

(1) to examine the influence of different organisms on algal decomposition, expressed in terms of percent algal dry weight loss (relative to the material introduced at time zero) at a given time and temperature;

(2) to examine the influence of untreated (raw) and treated seawater on algal decomposition;

(3) to examine the influence of a harpacticoid copepod species added to the microcosms after algal decomposition was already in progress.

(1) In the first experiment, 5 replicate microcosms were prepared for each treatment. Controls consisted of the air-dried algae in $50 \mathrm{ml}$ aged seawater, autoclaved and filtered through a $0.45 \mu \mathrm{m}$ cellulose nitrate membrane filter (Sartorius, Göttingen, FRG) to remove particulate matter. The yeast added was a pure culture of the common North Sea species Debaryomyces hansenii (Meyers et al., 1967) obtained from Prof. Dr. W. Gunkel, Helgoland. The yeast was cultivated on nutrient agar (Gunkel et al., 1983). After growth, the yeast cells were removed from the agar plates, suspended in about $10 \mathrm{ml}$ sterile seawater, and added in $1.5 \mathrm{ml}$ aliquots to the microcosms. Enumeration of the yeast cells was made on $0.45 \mu \mathrm{m}$ membrane filters (Meyers et al., 1967). Heterotrophic microflagellates originated from a surface sample of seawater taken from a pier at Helgoland in November 1988, which was enriched with diluted ZoBell 2216E medium (containing 
peptone and yeast extract). After several days incubation at $18^{\circ} \mathrm{C}$ in the dark with gentle agitation, a dense culture of flagellates appeared (method of Dr. K. Poremba, pers. comm.). Flagellates were enumerated with a Petroff-Hausser counting chamber; 10 fields were counted at $400 \times$ magnification, each field containing one large square with a volume of $8 \times 10^{-7} \mathrm{ml}$ (see Reichardt, 1978). Ciliates and nematodes were isolated from fresh algal fragments, primarily red algae, collected from the beach at Helgoland at low tide in November 1988. The algal fragments were transferred immediately onto cellulose agar plates (Rieper-Kirchner, 1989), flooded with raw seawater from the sampling site and incubated at $16^{\circ} \mathrm{C}$. After about $7 \mathrm{~d}$ a large number of nematodes (mostly Monhystera sp.) and ciliates (a mixture of large Euplotes sp. $60 \mu \mathrm{m}$ long, and a Uronema-like species 20-30 $\mu \mathrm{m}$ long) developed, which were subsequently used in the experiments. All nematodes were counted live with a Pasteur pipette. Ciliates were isolated from the cellulose-agar plates with a Pasteur pipette and transferred to fresh sterilized seawater. Ciliates were counted as follows: 0.5 to $1.0 \mathrm{ml}$ aliquots of seawater containing ciliates were fixed with formalin ( $1 \mathrm{ml} 37 \%$ formaldehyde + sample $+5 \mathrm{ml}$ sterilized, filtered seawater for greater volume). The fixed sample was immediately filtered onto a $0.45 \mu \mathrm{m}$ membrane filter and stained with $2 \%$ erythrosine in a $5 \%$ aqueous phenol solution (Reichardt, 1978, modified). A $1 \mathrm{~cm}^{2}$ piece of the filter was then cut out, placed on a slide, rendered transparent with immersion oil and counted under a standard Zeiss microscope at 160-400× magnification. Ten fields per slide were counted, with a maximum of 20 ciliates per field. Stained ciliates retain their shape and are readily distinguishable from detritus particles present.

Yeast cells, flagellates, nematodes and ciliates, with about 1.5 to $5 \mathrm{ml}$ of their culture fluid, were added to $50 \mathrm{ml}$ autoclaved, filtered seawater in each microcosm. The cultures were not axenic; bacteria adhering to the dried algal particles were also present in all microcosms. In addition, microcosms were also set up containing $5 \mathrm{ml} \mathrm{raw}$, untreated (unenriched) seawater sampled November 1988 and $50 \mathrm{ml}$ autoclaved filtered seawater as above; no other organisms were added. The bacteria in the microcosms were enumerated on ZoBell $2216 \mathrm{E}$ plates after suitable dilution (spread plates); plates were incubated $14 \mathrm{~d}$ at $20^{\circ} \mathrm{C}$ in the dark.

Experimental conditions: controls and microcosms containing yeast, flagellates, nematodes, ciliates, and untreated seawater alone were kept $14 \mathrm{~d}$ in the dark at $18^{\circ} \mathrm{C}$. All were continuously agitated on a table with gentle movement $\left(50 \mathrm{imp} \mathrm{min}^{-1}\right)$. The caps on the bottles were loosely placed to facilitate oxygen exchange. At the end of the experiment, the algal material was rinsed with distilled water, dried $4 \mathrm{~h}$ at $65^{\circ} \mathrm{C}$, and loss of dry weight was determined. The organisms were counted and the $\mathrm{pH}$ monitored in each microcosm at the end as at the beginning of the experiment.

(2) For the second experiment, raw untreated seawater was taken from the pier at Helgoland (surface water) in January 1989. One aliquot of the sample remained untreated, another was immediately filtered through a sterile $0.45 \mu \mathrm{m}$ filter, and a third was autoclaved. From each aliquot, $5 \mathrm{ml}$ were removed and added to $50 \mathrm{ml}$ autoclaved, filtered seawater with $0.1 \mathrm{~g}$ dried algae mixture as above. Five replicates were set up for each treatment. The duration and conditions were the same as under (1).

(3) For the third experiment, adult and late copepodid stages of the harpacticoid copepod Tisbe holothuriae from the author's stock cultures were used (Rieper, 1978). All copepods were counted live by means of Pasteur pipettes. For the first part of the 
experiment, $5 \mathrm{ml}$ of raw untreated seawater were added to 9 microcosms containing dried algae and $50 \mathrm{ml}$ autoclaved seawater as above. The untreated seawater originated from the same sample used in the second experiment described above, but had been stored overnight at $5^{\circ} \mathrm{C}$ before use. The 9 microcosms were kept $21 \mathrm{~d}$ at $18^{\circ} \mathrm{C}$ in the dark with

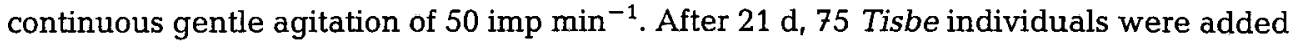
to each of 3 microcosms, with about $10 \mathrm{ml}$ culture water. To another 3 microcosms, $10 \mathrm{ml}$ copepod culture water without the copepods were added; the copepod cultures were not axenic and contained ciliates as a contaminant (a small Euplotes sp.) and microflagellates. The remaining 3 microcosms received no additional organisms.

After another 5 to $6 \mathrm{~d}$ under the same conditions, totalling 26-27 d experimental duration, the study was ended and analyses were performed as with the preceding experiments.

At the end of every experimental series, all meiofauna organisms were carefully removed from the algae by Pasteur pipette under a dissecting microscope. The algae fragments were rinsed with distilled water onto $180 \mu \mathrm{m}$ mesh size nylon gauze in order to remove the protozoans as far as possible, before the algal dry weight was determined. Small particles passing the $180 \mu \mathrm{m}$ gauze could not be separated from the protozoans and were not considered in the dry weight determinations.

\section{RESULTS}

\section{Experiment 1}

The results of the first experiment are summarized in Table 1. In microcosms with dried algae alone (controls) with no organisms added except bacteria adhering to the dried fragments, the mean algal dry weight loss after $14 \mathrm{~d}$ was $59.1 \%$. The numbers of bacteria, expressed as colony-forming units (cfu), increased from less than $10 \mathrm{ml}^{-1}$ at time zero to an average of $9 \times 10^{7} \mathrm{ml}^{-1}$ in the seawater at the end of the experiment. Over $90 \%$ of the colonies on the plates were pigmented yellow-ochre and appeared morphologically identical.

Addition of a pure culture of the yeast Debaryomyces hansenii: the concentration of yeast cells in each replicate after inoculation at time zero was $4 \times 10^{5} \mathrm{ml}^{-1}$, and increased after $14 \mathrm{~d}$ to about $8.6 \times 10^{6} \mathrm{ml}^{-1}$. Bacteria originating from the algal fragments developed after $14 \mathrm{~d}$ from less than $10 \mathrm{ml}^{-1}$ to an average of about $1 \times 10^{8} \mathrm{ml}^{-1}$, whereby yellow-ochre pigmented colonies dominated on the plates as above. The mean algal dry weight loss after $14 \mathrm{~d}$ amounted to $57.0 \%$. No other organisms were present.

Addition of heterotrophic microflagellates from enriched raw seawater sampled November 1988: the initial concentration of flagellates in the replicate microcosms was about $1 \times 10^{5} \mathrm{ml}^{-1}$ and increased after $14 \mathrm{~d}$ to a mean of $4 \times 10^{6} \mathrm{ml}^{-1}$ (range 1.8 to $5.6 \times 10^{6} \mathrm{ml}^{-1}$ ). The mean algal dry weight loss was $66.2 \%$. The bacteria numbers present with the flagellates at time zero were $2 \times 10^{4} \mathrm{cfu} \mathrm{ml}^{-1}$ and increased after $14 \mathrm{~d}$ to about $3 \times 10^{6} \mathrm{ml}^{-1}$. Non-pigmented colonies dominated; pigmented colonies were mostly lemon yellow.

Addition of nematode-ciliate mixture: 30 nematodes, primarily Monhystera sp., with a small number of mixed ciliate species as contaminants, were introduced to the microcosms at time zero. After $14 \mathrm{~d}$, in 4 of the 5 replicates there was an increase in the 


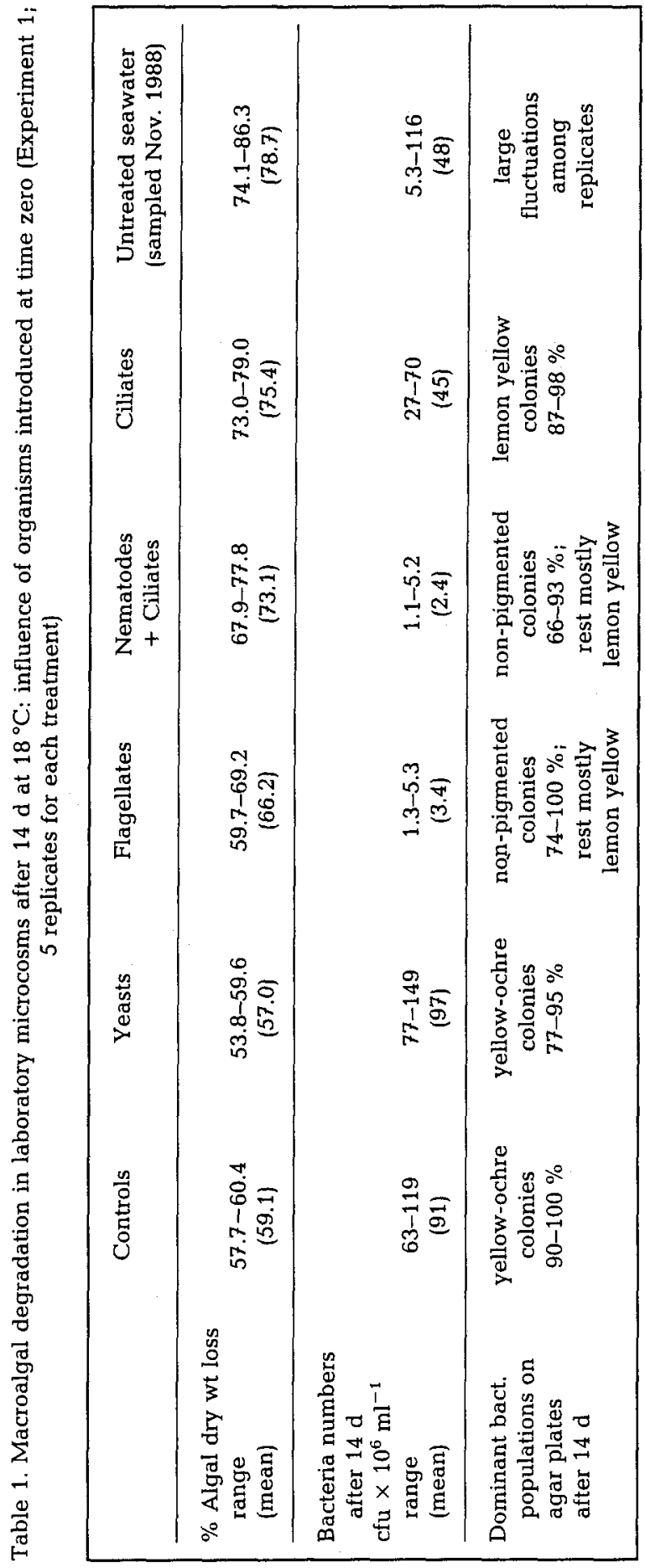


numbers of nematodes (to 200-595); in one replicate there was no change. (All the individual nematodes were not at the same stage of development when introduced to the microcosms.) The ciliate numbers (Euplotes and Uronema-like spp.) increased from about $170 \mathrm{ml}^{-1}$ to $1400-6400 \mathrm{ml}^{-1}$ after $14 \mathrm{~d}$. The microcosms with the highest numbers of nematodes had the fewest ciliates. The mean algal dry weight loss after $14 \mathrm{~d}$ was $73.1 \%$. The average numbers of bacteria present ranged from $3.5 \times 10^{4} \mathrm{ml}^{-1}$ at time zero to $2.4 \times 10^{6} \mathrm{ml}^{-1}$ after $14 \mathrm{~d}$, and consisted of forms with different morphological characteristics, the majority of which were not pigmented.

Addition of ciliates: at time zero, ciliates from the nematode cultures were introduced to the microcosms at a concentration of about 3000 ciliate individuals $\mathrm{ml}^{-1}$. After $14 \mathrm{~d}$, different ciliate populations developed in each replicate, their numbers ranging from $7 \times 10^{3}$ to $5 \times 10^{4} \mathrm{ml}^{-1}$. Dinoflagellates, not detected at time zero, also developed in each replicate and attained an average number of $1 \times 10^{5} \mathrm{ml}^{-1}$. Despite the various ciliate species and densities which developed, the bacteria numbers and forms in all replicates after $14 \mathrm{~d}$ were quite uniform. The average number was $4 \times 10^{7} \mathrm{ml}^{-1}$, most of which were lemon yellow pigmented $(87-98 \%)$. Initial concentrations were 3 powers of ten lower. The mean algal dry weight loss after $14 \mathrm{~d}$ was $75.4 \%$.

Addition of raw untreated seawater sampled November 1988: The initial bacteria counts in the replicates were $700 \mathrm{ml}^{-1}$. After $14 \mathrm{~d}$ the numbers increased, but at greatly differing rates. The final counts varied between $5 \times 10^{6} \mathrm{ml}^{-1}$ and $1 \times 10^{8} \mathrm{ml}^{-1}$. These large differences were also accompanied by variations in the morphology of the bacteria colonies: pigmented colonies, for example, which were mostly lemon yellow, ranged from $4 \%$ in one replicate to as much as $70 \%$ in another. Heterotrophic microflagellates developed in 2 of the 5 replicates. No ciliates, dinoflagellates or other organisms were observed. The mean algal dry weight loss after $14 \mathrm{~d}$ was $78.7 \%$. No correlation was apparent between the bacteria colonies, presence or absence of flagellates, and amount of algal dry weight loss. For example, in the 2 replicates where microflagellates were numerous enough to be determined with a counting chamber $\left(6 \times 10^{5}\right.$ and $\left.7 \times 10^{5} \mathrm{ml}^{-1}\right)$, $5.3 \times 10^{6}$ and $9.2 \times 10^{7} \mathrm{cfu} \mathrm{ml}^{-1}$, respectively, were found. In the former, $72 \%$ of the cfu were yellow pigmented, and less than $10 \%$ in the latter.

The $\mathrm{pH}$ values in all microcosms remained stable, ranging between 7.96 and 8.26 after $14 \mathrm{~d}$. All microcosms were examined microscopically at the end of the experiment. During decomposition, the macroalgal fragments became increasingly transparent, and the edges began to disintegrate. Small particles in the seawater were observed, the sizes of which were mostly between $40-400 \mu \mathrm{m}$. These particles apparently were aggregates of algal material and microorganisms, ciliates, flagellates and also nematodes. Smaller particles of about $20 \mu \mathrm{m}$ dominated in the control microcosms and those containing yeast.

\section{Experiment 2}

In the second experiment, the effects of untreated and treated seawater (filtered or autoclaved) on macroalgal decomposition were compared. The results are presented in Table 2.

Addition of raw untreated seawater (collected January 1989): the average bacteria numbers at time zero were about $300 \mathrm{ml}^{-1}$ and increased after $14 \mathrm{~d}$ to $1 \times 10^{8} \mathrm{ml}^{-1}$; nonpigmented forms dominated. Pigmented colonies were yellow or brown, and ranged from 
Table 2. Macroalgal degradation in laboratory microcosms after $14 \mathrm{~d}$ at $18^{\circ} \mathrm{C}$ : influence of raw untreated and treated seawater (sampled Jan. 1989) (Experiment 2; 5 replicates for each treatment)

\begin{tabular}{|lccc|}
\hline & Raw untreated & $0.45 \mu \mathrm{m}$ filtered & Autoclaved \\
\hline $\begin{array}{l}\text { \% Algal dry wt loss } \\
\text { range } \\
\text { (mean) }\end{array}$ & $\begin{array}{c}67.3-77.4 \\
(72.3)\end{array}$ & $\begin{array}{c}59.0-64.5 \\
(61.9)\end{array}$ & $\begin{array}{c}53.3-56.3 \\
(55.0)\end{array}$ \\
\hline $\begin{array}{l}\text { Bacteria numbers } \\
\text { after } 14 \mathrm{~d} \\
\text { cfu } \times 10^{6} \mathrm{ml}^{-1} \\
\text { range } \\
\text { (mean) }\end{array}$ & $\begin{array}{c}13-187 \\
(101)\end{array}$ & $\begin{array}{c}(25.1) \\
\text { yollow-ochre } \\
\text { colonies }\end{array}$ & $\begin{array}{c}51.5-155 \\
(89.8)\end{array}$ \\
\hline $\begin{array}{l}\text { Dominant bact. } \\
\text { populations on } \\
\text { agar plates }\end{array}$ & $\begin{array}{c}\text { mostly yellow } \\
\text { colonies; } \\
\text { total pigm. } \\
<1-28 \%\end{array}$ & $\begin{array}{c}14-100 \% \\
\text { colonies }\end{array}$ \\
\hline $\begin{array}{l}\text { Organisms present } \\
\text { after 14 d }\end{array}$ & $\begin{array}{c}\text { occasional } \\
\text { flagellates } \\
<10^{5} \mathrm{ml}\end{array}$ & no protozoans & no protozoans \\
\hline
\end{tabular}

less than $1 \%$ to about $30 \%$ of the total numbers. As with untreated seawater from November 1988, heterotrophic microflagellates developed in some but not in all replicates; their numbers were too few to be counted accurately with the counting chamber $\left(<10^{5} \mathrm{ml}^{-1}\right)$. The mean algal dry weight loss after $14 \mathrm{~d}$ was $72.3 \%$. In comparison to the microcosms containing seawater sampled November 1988, those with January 1989 seawater generally contained after $14 \mathrm{~d}$ higher numbers of bacteria with a lower percentage of pigmented forms, and the occurrence of microflagellates was negligible. The mean algal dry weight loss was lower than for the microcosms with November seawater $(78.7 \%$ as mean value with November seawater). Due to the large differences in the replicates containing seawater from November, however, a possible influence of the microflagellates on bacteria numbers and algal degradation could not be determined.

Addition of $0.45 \mu \mathrm{m}$-filtered seawater (from January 1989): bacteria counts at time zero in the microcosms were less than $10 \mathrm{ml}^{-1}$, and increased to $2.5 \times 10^{7} \mathrm{ml}^{-1}$ after $14 \mathrm{~d}$. While the cfu numbers were similar to the unfiltered samples, a much larger proportion of the forms present was yellow-ochre pigmented, and presumably originated from those bacteria adhering to the dried algal fragments. The mean dry weight loss was $61.9 \%$. No protozoans developed in any of the replicates.

Addition of autoclaved seawater (from January 1989): the bacteria in the microcosms at time zero were less than $10 \mathrm{ml}^{-1}$. After $14 \mathrm{~d}$, cfu numbers ranged from 5 to $15 \times 10^{7}$ $\mathrm{ml}^{-1}, 74-100 \%$ of which were yellow-ochre pigmented as above. The mean algal dry weight loss amounted to $55.0 \%$. No protozoans developed in the microcosms.

The $\mathrm{pH}$ values in all replicates of Experiment 2 remained stable between 7.8 and 8.26. Microscopical examination of the algal fragments after $14 \mathrm{~d}$ revealed small particles $40-400 \mu \mathrm{m}$. The particles in the replicates with autoclaved seawater tended to be finer. 
The bacteria which developed in the microcosms with filtered and autoclaved seawater were generally large $(1 \mu \mathrm{m} \times 1.8 \mu \mathrm{m}$, oval $)$ and non-motile. Some were coryneform. The bacteria in the untreated seawater, on the other hand, were smaller (about $0.5 \mu \mathrm{m}$ ) and more diverse forms were observed.

\section{Experiment 3}

In the third experiment, the macroalgal fragments were first incubated in raw untreated seawater (from the January 1989 sample) $21 \mathrm{~d}$ at $18^{\circ} \mathrm{C}$. After degradation was thus already in progress, the harpacticoid copepod Tisbe holothuriae and protozoans were introduced to 3 microcosms, 3 other microcosms received the copepod culture water with the protozoans but without Tisbe, and 3 microcosms were left unchanged. The experiment was terminated after another 5 to $6 \mathrm{~d}$ under the same conditions. The results are listed in Table 3.

Untreated seawater without addition of copepods or copepod culture water: after a total of $26 / 27$ d (analyses could not be completed on one day) the numbers of bacteria in the 3 replicates showed large differences, ranging from 4.5 to $170 \times 10^{6} \mathrm{ml}^{-1}$. Nonpigmented colonies dominated. No protozoans could be detected. The mean algal dry weight loss amounted to $78.4 \%$. pH values were between 8.08 und 8.26.

Untreated seawater with copepods (Tisbe holothuriae) added, including Tisbe culture water with ciliates and microflagellates: from the 75 copepods introduced to each microcosm, the numbers remaining after $5 \mathrm{~d}$ were 68,65 and 71 , respectively. Ciliates initially present at a density of less than $100 \mathrm{ml}^{-1}$ were only occasionally observed and apparently did not increase. The final concentrations of flagellates were 2 to $4 \times 10^{6} \mathrm{ml}^{-1}$.

Table 3. Macroalgal degradation in laboratory microcosms after $26 / 27 \mathrm{~d}$ at $18^{\circ} \mathrm{C}$ : influence of organisms introduced after $21 \mathrm{~d}$ (Experiment $3 ; 3$ replicates for each treatment)

\begin{tabular}{|c|c|c|c|}
\hline & $\begin{array}{l}\text { Untreated seawater } \\
\text { alone }\end{array}$ & $\begin{array}{l}\text { Untreated seawater } \\
+ \text { Tisbe holothuriae } \\
+ \text { ciliates, flagellates }\end{array}$ & $\begin{array}{l}\text { Untreated seawater } \\
\text { + copepod culture water } \\
\text { + ciliates, flagellates }\end{array}$ \\
\hline $\begin{array}{l}\text { \% Algal dry wt loss } \\
\text { range } \\
\text { (mean) }\end{array}$ & $\begin{array}{c}74.7-82.0 \\
(78.4)\end{array}$ & $\begin{array}{c}74.3-83.9 \\
(80.2)\end{array}$ & $\begin{array}{c}78.3-87.1 \\
(81.5)\end{array}$ \\
\hline $\begin{array}{l}\text { Bacteria numbers } \\
\text { after } 26 / 27 \mathrm{~d} \\
\text { cfu } \times 10^{6} \mathrm{ml}^{-1} \\
\text { range } \\
\text { (mean) }\end{array}$ & $\begin{array}{c}4.5-170 \\
(110)\end{array}$ & $\begin{array}{c}0.9-5.7 \\
(2.5)\end{array}$ & $\begin{array}{c}1.0-2.3 \\
(1.6)\end{array}$ \\
\hline $\begin{array}{l}\text { Dominant bact. } \\
\text { populations on } \\
\text { agar plates } \\
\text { after } 26 / 27 \mathrm{~d}\end{array}$ & $\begin{array}{c}\text { non-pigmented } \\
\text { colonies } \\
74-94 \%\end{array}$ & $\begin{array}{c}\text { non-pigmented } \\
\text { colonies } \\
67-97 \%\end{array}$ & $\begin{array}{l}\text { diff. pigmented } \\
\text { colonies } \\
31-74 \%\end{array}$ \\
\hline $\begin{array}{l}\text { Organisms present } \\
\text { after } 26 / 27 \mathrm{~d}\end{array}$ & $\begin{array}{l}\text { no copepods } \\
\text { no ciliates } \\
\text { no flagellates }\end{array}$ & $\begin{array}{l}\text { copepods (Tisbe) } \\
\text { very few ciliates } \\
\text { flag. } 2-4 \times 10^{6} \mathrm{ml}^{-1}\end{array}$ & $\begin{array}{c}\text { no copepods } \\
\text { very few ciliates } \\
\text { flag. } 2-7 \times 10^{6} \mathrm{ml}^{-1}\end{array}$ \\
\hline
\end{tabular}


The numbers of bacteria were between 0.9 and $5.7 \times 10^{6} \mathrm{ml}^{-1}$. Non-pigmented colonies dominated although different yellow and orange forms were not uncommon. The mean algal dry weight loss of $80.2 \%$ was not much greater than that without copepods and protozoans. The pH values were between 7.81 and 7.92 .

Untreated seawater with copepod culture water, ciliates and microflagellates: at the end of this part of the experiment, the numbers of ciliates were too few to be enumerated, whereas the flagellates reached a density of 2 to $7 \times 10^{6} \mathrm{ml}^{-1}$. The bacteria counts ranged from 1 to $2.3 \times 10^{6} \mathrm{ml}^{-1}$ and pigmented colonies (brown, gold-ochre, pink) were frequently observed. The mean algal dry weight loss was $81.5 \%$. The $\mathrm{pH}$ values were stable between 8.13 and 8.20. Algal particles $40-400 \mu \mathrm{m}$ were observed in all microcosms, as in the previous experiments.

\section{DISCUSSION}

As shown in Table 1, with only air-dried macroalgal fragments present in sterile seawater, over half the algal dry weight is lost after $14 \mathrm{~d}$, apparently due to initial leaching processes and the activity of bacteria adhering to the fragments. During this period high numbers of bacteria developed, over $90 \%$ of which were uniformly yellowochre pigmented and apparently morphologically identical.

Although yeasts have often been reported in the marine environment and may rapidly multiply in the presence of algae in the laboratory, for example from $10^{3}$ to $10^{8}$ cells $\mathrm{ml}^{-1}$ within 3 weeks with Desmarestia viridis (Gunkel et al., 1983), the addition of the common North Sea yeast Debaryomyces hansenii did not increase the rate of algal decomposition. Instead, with yeast added, a lower percentage of algal dry weight loss was noted compared to the controls above. It is possible that the rapid development of yeast cells in the microcosms to several million $\mathrm{ml}^{-1}$, exceeding values encountered in the field (maximally 500 cells $\mathrm{cm}^{3}$ fresh sediment and less than $100 \mathrm{ml}^{-1}$ in surf water with algal fragments: author's unpubl. data), interfered with the bacterial activity.

According to results of investigations on macrophyte material by workers such as Fenchel (1970) and Robertson et al. (1982), who employed the acridine orange direct counting method for enumerating flagellates, the densities of $4 \mu \mathrm{m}$ flagellates in the microcosms in this study $\left(10^{5}\right.$ to $\left.10^{6} \mathrm{ml}^{-1}\right)$ may be considered realistic. Compared to the controls, a higher mean algal dry weight loss and lower numbers of bacteria occurred (Table 1). Similar results have also been reported by Johannes (1965), who found the regeneration of dissolved organic phosphate from detritus proceeded faster in the presence of colorless flagellates $1-4 \mu \mathrm{m}$ as well as ciliates. The microbial decomposition of dead Peridinium (dinoflagellate) cells was also accelerated in the presence of bacterivorous 2-10 $\mu \mathrm{m}$ microflagellates (Sherr et al., 1982). On the other hand, Javornický \& Prokešová (1963) showed that while the development of ciliates and larger flagellates in freshwater samples reduced bacterial numbers and increased the oxidation processes, the presence of minute colorless flagellates did not greatly reduce the numbers of bacteria or significantly influence the oxygen consumption. The role of microflagellates in decomposition processes will no doubt depend not only on the bacteria and dissolved nutrients in a given body of water, but also on the regulatory mechanism of larger protozoans present.

Indisputable is the stimulation of bacterial activity reported for ciliated protozoans (Bick, 1967; Barsdate et al., 1974; Briggs et al., 1979; Rogerson \& Berger, 1983; Rieper- 
Kirchner, 1989, and the present study). What are the mechanisms of protozoan stimulation of bacterial activity? Protozoan predation reduces the numbers of bacteria and may thus keep the bacteria in an active metabolic state (Javornický \& Prokešová, 1963). It has also been suggested that protozoans release metabolites into the environment which are utilized by bacteria (Straškrabová-Prokešová \& Legner, 1966; Legner, 1973). Protozoan stimulation of bacterial activity could also be due to the release of nutrients from the bacterial cells themselves, which are preyed upon (Huang et al., 1981; Taylor et al., 1985).

Similar mechanisms may also apply to bacterial stimulation in the presence of small metazoans, although in this respect data is sparse. Over 25 years ago, Javornický \& Prokešová (1963) suggested that "Higher zooplankton may decrease bacterial numbers and thus stimulate the oxidation process in a similar way to Protozoa". This is supported by the findings of Tenore et al. (1977), Findlay \& Tenore (1982) and Rieper-Kirchner (1989) with various species of free-living nematodes. In the present study, the nematodes in the decomposition experiments were introduced with their accompanying ciliates, since laboratory stock cultures of nematodes appeared less robust und degenerated more rapidly than those with bacterivorous ciliates present. The mean algal dry weight loss, however, was greater with higher numbers of mixed ciliate species without the nematodes (Table 1). Possibly the ciliates and nematodes were competing for nutrients in the small closed systems (Stenson, 1984).

Although these results appear to demonstrate an enhancement of bacterial activity due to the presence of protozoans and nematodes, unexpectedly the highest algal dry weight losses were found with raw seawater alone (Tables 1 and 2): $78.7 \%$ with the sample from November 1988 and $72.3 \%$ from the same site taken January 1989. Filtering through a $0.45 \mu \mathrm{m}$ membrane filter removed much of the sample's effect on algal dry weight loss, and autoclaving the seawater reduced the weight loss to $55.0 \%$. The different results from the November and January seawater samples may be due to seasonal variations in the microorganisms present which are active in algal decomposition (Rieper-Kirchner, 1989). Although during the 14-d experiments some flagellates developed in several replicates, their presence could not be correlated with the algal dry weight losses in these microcosms. Large differences in the numbers of bacteria (cfu) as well as in the proportion of pigmented colonies were found which could not be correlated with either algal dry weight loss or presence of flagellates. The organisms primarily responsible for the algal decomposition in this experimental series are presumably bacteria from raw seawater which do not pass a $0.45 \mu \mathrm{m}$ filter due to a larger cell size or to the formation of filaments or extracellular slime. These are apparently mixed populations of opportunists including the lemon yellow forms observed, which are able to replace the large yellow-ochre forms originally adhering to the dried algal fragments. These bacteria should have been present in the flagellate-enriched microcosms (Table 1), since the flagellates were cultivated in raw seawater from the same sampling site. Did the process of enrichment put the actively degrading bacteria at a disadvantage? If these bacteria were outcompeted or ingested by the microflagellates, then the decomposition may have been actually impeded rather than enhanced by these protozoans. Was the spread plate method suitable for enumeration of bacteria in these studies? Although higher bacteria numbers may be obtained with direct counting methods, the saprophytes which develop on $2216 \mathrm{E}$ medium are primarily those which are actively involved in the decomposition of 
easily decomposable organic matter such as protein and carbohydrates (Rheinheimer, 1984). When bacteria numbers from a stranded Macrocystis kelp bed were compared using acridine orange direct counts and viable cell counts in $2216 \mathrm{E}$ medium (MPN, most probable numbers), Bouvy et al. (1986) found the ratio of direct counts to viable counts reached values close to 1 . Similarly, Corre et al. (1989) found good agreement for bacteria counts on Laminaria digitata debris determined with scanning electron microscopy and $2216 \mathrm{E}$ plate counts. This suggests that the discrepancy between direct and viable counts may be negligible when a sufficient nutrient supply is available. A complete agreement with direct and viable counts, however, is unlikely, due to the occurrence of inactive bacteria cells.

In this present study no attempt was made to identify taxonomically the bacterial colonies which developed during algal decomposition. Numerous investigations on bacteria associated with macroalgae indicate that the genera Vibrio, Pseudomonas, Flavobacterium, and Leucothrix are frequently represented; yellow ("flavobacteria") and brown pigmented forms frequently occur (Chan \& McManus, 1969; Laycock, 1974; Cundell et al., 1977; Hollohan et al., 1986; Bolinches et al., 1988; Corre et al., 1989).

With regard to the meiofauna, next to nematodes harpacticoid copepods are the most abundant in sediment biotopes as well as in the phytal (Coull, 1988). Although a few species of harpacticoids may feed directly on macroalgal tissue, detritus and the associated microbiota is considered one of their major food sources (Hicks \& Coull, 1983; Meyer \& Bell, 1989). Specific strains of bacteria may also be preferred (Rieper, 1982). Recently, harpacticoids have been reported in sea foam, where they may feed on microorganisms or on other organic components of the foam itself (Armonies, 1989). Some data indicate that meiofauna, in particular nematodes and possibly also harpacticoids, play a role in making detritus available to macrofauna (Tenore et al., 1977). Preliminary investigations on the role of harpacticoids in algal decomposition indicate that, at least in closed systems, these organisms do not survive initial degradation processes (Rieper-Kirchner, 1989), due perhaps to harmful algal leachates, bacterial metabolic products or oxygen deficit. In the present study (part of Experiment 3), Tisbe holothuriae introduced to microcosms after degradation had been in progress for 3 weeks were able to survive, but their effect on algal dry weight loss was negligible (Table 3). A slight stimulatory effect may have been due to the presence of the contaminant protozoans in the copepod culture water. This apparent lack of influence by Tisbe compared to that of the nematodes was unexpected, considering the role of detritus and microorganisms in the natural diet of harpacticoids. In other studies, the harpacticoid copepods $T$. holothuriae and Paramphiascella vararensis readily consumed bacterial aggregates produced in the laboratory by bacterial growth on dissolved organic matter derived from macroalgae (method of Biddanda, 1985), as evidenced by the large numbers of fecal pellets produced (RieperKirchner et al., in prep.). The extent to which the bacteria are digested has not been determined, although these harpacticoid species are able to survive in the laboratory on a diet of bacteria alone (Rieper, 1978).

The results of the present study may be summarized as follows:

(1) Decomposition rates of North Sea macroalgae were studied in laboratory microcosms.

The mean amounts of algal dry weight loss after $14 \mathrm{~d}$ at $18^{\circ} \mathrm{C}$ ranged from 55 to $80 \%$, and are comparable to those found for North Sea algae in the field (Rieper-Kirchner, 1989). 
(2) The addition of yeast did not increase the algal decomposition rate.

(3) The presence of protozoans (bacterivorous ciliates, flagellates) may enhance microbial decomposition processes, depending on the populations of bacteria originally present in the inoculum.

(4) Meiofaunal organisms such as nematodes may also facilitate bacterial decomposition; the influence of the harpacticoid copepod Tisbe holothuriae, on the other hand, could not be demonstrated.

(5) Primary agents in the macroalgal decomposition are mixed species of opportunistic bacteria occurring in natural seawater, larger than $0.45 \mu \mathrm{m}$, and frequently yellow pigmented.

(6) In all microcosms during the degradation experiments, the formation of algal particles $40-400 \mu \mathrm{m}$ was observed, which were rapidly colonized by the other organisms present. These enriched particles may constitute food for macroconsumers in the marine environment.

\section{LITERATURE CITED}

Armonies, W., 1989. Occurrence of meiofauna in Phaeocystis seafoam. - Mar. Ecol. Prog. Ser. 53, 305-309.

Barsdate, R. J., Prentki, R. T. \& Fenchel, T., 1974. Phosphorus cycle of model ecosystems: significance for decomposer food chains and effect of bacterial grazers. - Oikos 25, 239-251.

Bick, H., 1967. Vergleichende Untersuchungen der Ciliatensukzession beim Abbau von Pepton und Cellulose (Modellversuche). - Hydrobiologia 30, 353-373.

Biddanda, B. A., 1985. Microbial synthesis of macroparticulate matter. - Mar. Ecol. Prog. Ser. 20 , 241-251.

Bolinches, J., Lemos, M. L. \& Barja, J. L., 1988. Population dynamics of heterotrophic bacterial communities associated with Fucus vesiculosus and Ulva rigida in an estuary. - Microb. Ecol. 15 , 345-357.

Bouvy, M., Le Romancer, M. \& Delille, D., 1986. Significance of microheterotrophs in relation to the degradation process of subantarctic kelp beds (Macrocystis pyrifera). - Polar Biol. 5, 249-253.

Briggs, K. B., Tenore, K. R. \& Hanson, R. B., 1979. The role of microfauna in detrital utilization by the polychaete, Nereis succinea (Frey and Leuckart). - J. exp. mar. Biol. Ecol. 36, 225-234.

Chan, E. C. S. \& McManus. E. A., 1969. Distribution, characterization, and nutrition of marine microorganisms from the algae Polysiphonia lanosa and Ascophyllum nodosum. - Can. J. Microbiol. 15, 409-420.

Corre, S., Prieur, D., Chamroux, S., Floch, J.-Y. \& Hourmant, A., 1989. Caractérisation des communautés bactériennes épiphytes de frondes de Laminaria digitata et de débris résultant de leur fragmentation. - Cah. Biol. mar. 30, 115-130.

Coull, B. C., 1988. Ecology of the marine meiofauna. In: Introduction to the study of meiofauna. Ed. by R. P. Higgins \& $H$. Thiel. Smithsonian Institution Press, Washington, D. C., 18-38.

Cundell, A. M., Sleeter, T. D. \& Mitchell, R., 1977. Microbial populations associated with the surface of the brown alga Ascophyllum nodosum. - Microb. Ecol, 4, 81-91.

Fenchel, T., 1970. Studies on the decomposition of organic detritus derived from the turtle grass Thalassia testudinum. - Limnol. Oceanogr. 15, 14-20.

Fenchel, T. \& Harrison, P., 1976. The significance of bacterial grazing and mineral cycling for the decomposition of particulate detritus. In: The role of terrestrial and aquatic organisms in decomposition processes. Ed. by J. M. Anderson \& A. Macfayden. Blackwell, Oxford, 285-299.

Fenchel, T. M. \& Jørgensen, B. B., 1977. Detritus food chains of aquatic ecosystems: the role of bacteria. In: Advances in microbial ecology. Ed. by M. Alexander. Plenum Press, New York, 1, $1-58$.

Findlay, S. \& Tenore, K. R., 1982. Effect of a free-living marine nematode (Diplolaimella chitwoodi) on detrital carbon mineralization. - Mar. Ecol. Prog. Ser. 8, 161-166. 
Griffiths, C. L. \& Stenton-Dozey, J., 1981. The fauna and rate of degradation of stranded kelp. Estuar, coast. Shelf Sci. 12, 645-653.

Gunkel, W., Crow, S. \& Klings, K.-W., 1983. Yeast population increases during degradation of Desmarestia viridis (Phaeophyceae) in seawater model microecosystems. - Mar. Biol. 75, $327-332$.

Harrison, P. G. \& Mann, K. H., 1975. Detritus formation from eelgrass (Zostera marina L.): The relative effects of fragmentation, leaching, and decay. - Limnol. Oceanogr. 20, 924-934.

Heip, C., Vincx, M. \& Vranken, G., 1985. The ecology of marine nematodes. - Oceanogr. mar. Biol. 23, 399-489.

Hicks, G. R. F. \& Coull, B. C., 1983. The ecology of marine meiobenthic harpacticoid copepods. Oceanogr. mar. Biol. 21, 67-175.

Higgins, R. P. \& Thiel, H., 1988. Prospectus. In: Introduction to the study of meiofauna. Ed. by R. P. Higgins \& H. Thiel. Smithsonian Institution Press, Washington, D. C., 11-13.

Hollohan, B. T., Dabinett, P. E. \& Gow, J. A., 1986. Bacterial succession during biodegradation of the kelp Alaria esculenta (L.) Greville. - Can. J. Microbiol. 32, 505-512.

Huang, T.-C., Chang, M.-C. \& Alexander, M., 1981. Effect of Protozoa on bacterial degradation of an aromatic compound. - Appl. environ. Microbiol. 41, 229-232.

Inglis, G., 1989. The colonisation and degradation of stranded Macrocystis pyrifera (L.) C. Ag. by the macrofauna of a New Zealand sandy beach. - J. exp. mar. Biol. Ecol. 125, 203-217.

Javornický, P. \& Prokešová, V., 1963. The influence of Protozoa and bacteria upon the oxidation of organic substances in water. - Int. Revue ges. Hydrobiol. 48, 335-350.

Johannes, R. E., 1965. Influence of marine Protozoa on nutrient regeneration. - Limnol. Oceanogr. $10,434-442$.

Koop, K., Newell, R. C. \& Lucas, M. I., 1982a. Biodegradation and carbon flow based on kelp (Ecklonia maxima) debris in a sandy beach microcosm. - Mar. Ecol. Prog. Ser. 7, 315-326.

Koop, K., Newell, R. C. \& Lucas, M. I., 1982b. Microbial regeneration of nutrients from the decomposition of macrophyte debris on the shore. - Mar. Ecol. Prog. Ser. 9, 91-96.

Laycock, R. A., 1974. The detrital food chain based on seaweeds. I. Bacteria associated with the surface of Laminaria fronds. - Mar. Biol. 25, 223-231.

Legner, M., 1973. Experimental approach to the role of Protozoa in aquatic ecosystems. - Am. Zool. 13, 177-192.

Linley, E. A. S., Newell, R. C. \& Bosma, S. A., 1981. Heterotrophic utilisation of mucilage released during fragmentation of kelp (Ecklonia maxima and Laminaria pallida). I. Development of microbial communities associated with the degradation of kelp mucilage. - Mar. Ecol. Prog. Ser. $4,31-41$.

Lorenzen, S., Prein, M. \& Valentin, C., 1987. Mass aggregations of the free-living marine nematode Pontonema vulgare (Oncholaimidae) in organically polluted fjords. - Mar. Ecol. Prog. Ser. 37. 27-34.

Lucas, M. I., Newell, R. C. \& Velimirov, B., 1981. Heterotrophic utilisation of mucilage released during fragmentation of kelp (Ecklonia maxima and Laminaria pallida). II. Differential utilisation of dissolved organic components from kelp mucilage. - Mar. Ecol. Prog. Ser. 4, 43-55.

Lüning, K., 1985. Meeresbotanik. Thieme, Stuttgart, $375 \mathrm{pp}$.

Lush, D. L. \& Hynes, H. B. N., 1973. The formation of particles in freshwater leachates of dead leaves. - Limnol. Oceanogr. 18, 968-977.

Mann, K. H., 1972. Macrophyte production and detritus food chains in coastal waters. - Mem. Ist. ital. Idrobiol. 29 (Suppl.), 353-383.

Meyer, H. A. \& Bell, S. S., 1989. Response of harpacticoid copepods to detrital accumulation on seagrass blades: a field experiment with Metis holothuriae (Edwards). - J. exp. mar. Biol. Ecol. $132,141-149$.

Meyers, S. P., Ahearn, D. G., Gunkel, W. \& Roth, F. J., 1967. Yeasts from the North Sea. - Mar. Biol. $1,118-123$.

Muschenheim, D. K., Kepkay, P. E. \& Kranck, K., 1989. Microbial growth in turbulent suspension and its relation to marine aggregate formation. - Neth. J. Sea Res. 23, 283-292.

Reichardt, W., 1978. Einführung in die Methoden der Gewässermikrobiologie. Fischer, Stuttgart, $250 \mathrm{pp}$.

Rheinheimer, G., 1981. Mikrobiologie der Gewässer. Fischer, Stuttgart, 251 pp. 
Rheinheimer, G., 1984. Bacterial ecology of the North and Baitic Seas. - Botanica mar. 27, 277-299. Riemann, F., 1968. Nematoden aus dem Strandanwurf. - Veröff. Inst. Meeresforsch. Bremerhaven $11,25-35$.

Rieper, M., 1978. Bacteria as food for marine harpacticoid copepods. - Mar. Biol. 45, 337-345.

Rieper, M., 1982. Feeding preferences of marine harpacticoid copepods for various species of bacteria. - Mar. Ecol. Prog. Ser. 7, 303-307.

Rieper-Kirchner, M., 1989. Microbial degradation of North Sea macroalgae: field and laboratory studies. - Botanica mar. 32, 241-252.

Robertson, A. I. \& Hansen, J. A., 1982. Decomposing seaweed: a nuisance or a vital link in coastal food chains? - Res. Rep. Div. Fish. C. S. I. R. O. 1980-1981, 75-83.

Robertson, M. L., Mills, A. L. \& Zieman, J. C., 1982. Microbial synthesis of detritus-like particulates from dissolved organic carbon released by tropical seagrasses. - Mar. Ecol. Prog. Ser. 7, 279-285.

Rogerson, A. \& Berger, J., 1983. Enhancement of the microbial degradation of crude oil by the ciliate Colpidium colpoda. - J. gen. appl. Microbiol. 29, 41-50.

Sherr, B. F., Sherr, E. B. \& Berman, T., 1982. Decomposition of organic detritus: a selective role for microflagellate Protozoa. - Limnol. Oceanogr. 27, 765-769.

Stenson, J. A. E., 1984. Interactions between pelagic metazoan and protozoan zooplankton, an experimental study. - Hydrobiologia 111, 107-112.

Straškrabová-Prokešová, V. \& Legner, M., 1966. Interrelations between bacteria and Protozoa during glucose oxidation in water. - Int. Revue ges. Hydrobiol. 51, 279-293.

Taylor, G. T., Iturriaga, R. \& Sullivan, C. W., 1985. Interactions of bactivorous grazers and heterotrophic bacteria with dissolved organic matter. - Mar. Ecol. Prog. Ser. 23, 129-141.

Tenore, K. R., Tietjen, J. H. \& Lee, J. J., 1977. Effect of meiofauna on incorporation of aged eelgrass, Zostera marina, detritus by the polychaete Nephthys incisa. - J. Fish. Res. Bd Can. 34, 563-567.

Wolter, K. \& Rheinheimer, G., 1977. Bakteriologische Untersuchungen an in der Brandungszone angetriebenem Algenmaterial. - Botanica mar. 20, 171-181. 